\title{
Aspek Sosiologis dalam Novel di Bawah Langit yang Sama Karya Helga Rif
}

\author{
Putri Mayang Astuti*, Sri Jumadiah \\ Prodi Sastra Indonesia, Fakultas Ilmu Budaya, Universitas Udayana \\ Email: puputmayang021@gmail.com] \\ Badung, Bali, Indonesia \\ *Corresponding Author
}

\begin{abstract}
This study aims to describe (1) the structure that builds the novel Di Bawah langit yang Samaby Helga Rif; and (2) the sociological aspects contained in the novel Di Bawah Langit yang Sama by Helga Rif. The theory used in this research is Stanton's structural theory and literary sociology Ian Watt. Data collection methods used are library methods as well as reading and note-taking techniques. Data analysis was performed using descriptive analytic methods. Data analysis techniques using reading, interpretive, and note taking techniques. The results of this study indicate that the intrinsic elements analyzed in the novel under the same sky include: characterizations, plots, and settings. The sociological aspects analyzed in the novel Di Bawah Langit yang Sama are social aspects, moral aspects, education aspects, economic aspects, and love aspects. Social aspects are shown in the lives of Balinese people. Moral aspects found are good morals. The educational aspects analyzed include formal and informal education. Economic aspects are analyzed using social stratification, namely upper class and middle class society. Aspects of romance discuss the love of different religions between Indira and Maximilian.
\end{abstract}

Keywords: Novel, Social Aspects, Bali Society.

\begin{abstract}
Abstrak
Penelitian ini bertujuan mendeskripsikan (1)struktur yang membangun novel $D i$ Bawah Langit yang Sama karya Helga Rif;dan (2) aspek sosiologis yang terkandung dalam novel Di Bawah Langit yang Sama karya Helga Rif.Teori yang digunakan dalam penelitian ini merupakan teori struktural Stanton dan sosiologi sastra Ian Watt. Metode pengumpulan data yang digunakan adalah metode kepustakaan serta teknik baca dan catat.Analisis data dilakukan dengan metode deskriptif analitik.Teknik analisis data menggunakan teknik baca, interpretatif, dan catat.Hasil penelitian ini menunjukkan bahwaunsur intrinsik yang dianalisis pada novel Di Bawah Langit yang Sama meliputi: penokohan, plot, dan latar. Aspek sosiologis yang dianalisis pada novel Di Bawah Langit yang Sama yaitu: aspek sosial, aspek moral, aspek pendidikan, aspek ekonomi, dan aspek percintaan. Aspek sosial ditunjukkan pada kehidupan masyarakat Bali. Aspek moral yang ditemukan yaitu, moral baik.Aspek pendidikan yang dianalisis meliputi pendidikan formal dan informal. Aspek ekonomi dianalisis dengan menggunakan stratifikasi sosial, yaitu masyarakat kelas atas dan masyarakat kelas menengah. Aspek percintaan membahas tentang cinta beda agama antara Indira dengan Maximilian.
\end{abstract}

Kata Kunci : Novel, Aspek Sosial, Masyarakat Bali. 


\section{PENDAHULUAN}

Cabang kesenian yang menggunakan bahasa sebagai alat pemaparannya yaitu, karya sastra. Dalam membuat karya sastra bahasa yang digunakan memiliki kekhasan. Kehadiran karya sastra di dalam kehidupan manusia dapat diterima sebagai kenyataan sosial budaya.

Karya sastra terbagi menjadi tiga jenis, yaitu: prosa, puisi, dan drama. Prosa juga dibagi beberapa jenis, yaitu: cerpen, novel, dan roman. Pada penelitian ini karya sastra yang menjadi objek penelitian adalah novel yang berjudul Di Bawah Langit yang Sama (disingkat $D B L S$ ) karya Helga Rif. Dalam buku The Advanced Learner's Dictionary of Current English dijelaskan bahwa novel adalah suatu cerita yang memiliki plot panjang dan mengisahkan kehidupan manusia yang bersifat khayalan (dalam Tarigan, 2015:167).

Novel $D B L S$ dijadikan objek penelitian ini karena beberapa pertimbangan. Pertama, novel ini mengandung aspek sosiologis yang kuat. Hal ini tampak pada tokoh Indira yang bekerja di Singapura yang mencintai atasannya, mereka memiliki perbedaan agama, adat istiadat, dan status sosial. Kedua, novel $D B L S$ karya Helga Rif diterbitkan oleh Gagasmedia pada tahun 2015, tebal novel ini 266 halaman. Disamping novel $D B L S$, Helga Rif juga menulis novel Gara-Gara Irana Jadi Arini (1997), Menemukanmu (2011), Kepingan Cinta Lalu (2012), Melepaskanmu (2012), First Love (2014), dan Let Me Love You (2017). Helga Rif hanya nama pena beliau. Helga Rif lahir di Kabupaten Situbondo, Jawa Timur pada 28 Maret 1981. Beliau merupakan alumnus mahasiswa Jurusan Ilmu Ekonomi Pembangunan, Fakultas Ekonomi, Universitas Udayana pada tahun 2003. Selain menjadi penulis, dulu beliau adalah seorang model. Saat ini, kegiatan beliau mengajar modeling di John Robert Powers. Beliau juga menjadi atlet menembak Kota Denpasar dan membantu suaminya di Sakabros Event Organizer. Ketiga, belum adanya penelitian menggunakan teori sosiologi sastra pada novel $D B L S$. Dari beberapa aspek yang terdapat dalam novel $D B L S$, aspek yang diteliti pada penelitian ini adalah: aspek sosial, aspek moral, aspek pendidikan, aspek ekonomi, dan aspek percintaan.

Penelitian sebelumnya yang berkaitan dengan penelitian ini, yaitu Pamungkas Tri Prasetyo (2013) "Kajian Sosiologi Sastra dalam Novel Kubur Ngemut Wewadi karya A.Y. Suharyono dan Kemungkinan Pembelajarannya di Kelas XI SMA", Syarifuddin (2018) "Kajian Struktural dan Sosiologi Sastra dalam Novel yang diteliti pada penelitian ini adalah: aspek sosial, aspek moral, aspek pendidikan, aspek ekonomi, dan aspek percintaan.Seputih Hati yang Tercabik karya Ratu Wardarita", Nur Laili Ihsan (2018) "Upacara Kematian dalam Tradisi suku Toraja dalam Novel Puya ke Puya karya Faisal Oddang: Kajian Sosiologi Sastra", Rahmat Gunawan dkk (2019) "Aspek-Aspek Sosial Novel Rantau 1 Muara karya Ahmad Fuadi", Dedy Prasetiyo (2017) "Analisis Aspek Sosiologi Sastra dalam Novel Kidung Cinta Buat Pak Guru karya Mira". Penelitian-penelitian di atas memiliki kesamaan dengan penelitian ini, yaitu menjelaskan aspek-aspek sosial yang terdapat di dalam objek penelitian. Dengan demikian, kajian sosiologi sastra pada novel $D B L S$ belum pernah dilakukan.

Berdasarkan uraian di atas, permasalahan yang dibahas dalam penelitian ini, yaitu: (1) Bagaimanakah struktur novel yang meliputi: plot, penokohan, dan latar yang membangun novel DBLS? dan (2) Bagaimanakah aspek sosiologis yang meliputi: aspek sosial, aspek moral, aspek pendidikan,aspek ekonomi, dan aspek percintaan yang terkandung dalam novel $D B L S$ ?

\section{METODE}

Sumber data yang digunakan pada penelitian ini adalah novel $D B L S$ karya Helga Rif. Metode dan teknik pengumpulan data menggunakan metode kepustakaan, kemudian dilanjutkan dengan menggunakan teknik baca dan catat. Pada tahapan menganalisis data digunakan metode deskriptif analitik sertamenggunakan teknik baca, interpretatif, dan catat. Penyajian hasil analisis data menggunakan metode deskriptif dan teknik mengikuti sistematika penulisan skripsi. 


\section{KERANGKA TEORI}

Penelitian dengan menggunakan kajian sosiologi sastra sudah banyak dilakukan. Arianto pada skripsinya yang berjudul "Novel Midah Simanis Bergigi Emas karya Pramoedya Ananta Toer: Kajian Sosiologi Sastra", mahasiswa progam studi Sastra Indonesia, Fakultas Sastra, Universitas Udayana, tahun 2009. Hasil penelitiannya yaitu, menganalisis struktur-struktur dan aspek-aspek sosiologis yang terdapat pada novel Midah Simanis Bergigi Emas.

Penelitian dengan memakai objek novel $D B L S$ karya Helga Rif sudah pernah dilakukan. Anna Dwi Lestari pada skripsinya yang berjudul "Representasi Kebudayaan Bali dalamNovel Di Bawah langit yang Sama karya Helga Rif (Kajian Interpretatif Simbolik Clifford Geertz)", mahasiswa program studi Pendidikan Bahasa dan Sastra Indonesia, Fakultas Bahasa dan Seni, Universitas Negeri Surabaya, tahun 2018. Hasil penelitiannya yaitu, rencana-rencana, resep-resep, aturan-aturan, dan instruksiinstruksi masyarakat Bali yang terepresentasi dalam novel $D B L S$.

Persamaan dan perbedaan penelitian tersebut dengan penelitian ini, terletak pada kajian yang digunakan dan objek yang diteliti. Penelitian Arianto menggunakan kajian yang sama dengan penelitian ini, yaitu kajian sosiologi sastra. Perbedaannya terdapat pada objek yang diteliti, penelitian Arianto memakai novel Midah Simanis Bergigi Emas karya Pramoedya Ananta Toer, sedangkan penelitian ini menggunakan novel $D B L S$ karya Helga Rif.

Pada penelitian Anna Dwi Lestari memakai objek yang sama dengan penelitian ini, yaitu novel $D B L S$ karya Helga Rif. Perbedaannya terdapat pada kajian yang digunakan, penelitian Anna Dwi Lestari memakai kajian interpretatif simbolik Clifford Geertz, sedangkan penelitian ini menggunakan kajian sosiologi sastra.

Teori yang dipakai dalam menganalisis novel DBLS adalah teori struktural Stanton dan sosiologi sastra Ian Watt. Pada buku $A n$ Introduction to Fiction Stanton mengatakan, unsur fiksi dibagi menjadi fakta cerita, sarana cerita, dan tema (dalam Wiyatmi, 2009:2930). Berdasarkan penjelasan di atas, unsur- unsur intrinsik yang dianalisis pada penelitian ini, yaitu fakta cerita yang mencakup: plot, penokohan, dan latar. Pendapat dari Ian Watt yang digunakan pada penelitian ini adalah sastra sebagai cermin masyarakat. Aspek sosiologis yang dianalisis pada penelitian ini, yaitu: aspek sosial, aspek moral, aspek pendidikan, aspek ekonomi, dan aspek percintaan.

\section{HASIL DAN PEMBAHASAN}

\section{Analisis Struktural}

a. Penokohan

Lajos Egri mengatakan, adanya tiga dimensi dalam perwatakan tokoh sebagai struktur pokoknya, yaitu fisiologis, sosiologis, dan psikologis (dalam Sukada, 1987:62). Selanjutnya menurut Sudjiman, tokoh dibagi atas tokoh utama, tokoh sekunder, dan tokoh komplementer. Pembagian tokoh tersebut dapat dilihat dari segi peranan dan keterlibatan tokoh dalam cerita (dalam Siswanto, 2013:129). Berdasarkan pendapat di atas, dalam menganalisis tokoh novel $D B L S$ dibagi menjadi tiga, yaitu: tokoh utama adalah Indira; tokoh sekunder adalah Maximilian, Gung Wah, dan orang tua Indira; serta tokoh komplementer adalah Iswari, teman Indira, Tante Rani, dan Gus Brahma. Kemudian, penokohannya dapat dianalisis melalui dimensi fisiologis, sosiologis, dan psikologis.

b. Plot

Plot adalah peristiwa yang disebabkan oleh sebab akibat. Tahapan plot yang digunakan dalam menganalisis novel $D B L S$ karya Helga Rif berdasarkan pendapat dari Tasrif, yaitu: tahap penyituasian (tahap situation), tahap pemunculan konflik (tahap generating circumstances), tahap peningkatan konflik (tahap rising action), tahap klimaks (tahap climax), dan tahap tahap penyelesaian (tahap denouement) (dalam Nurgiyantoro, 2012:149-150). Salah satu contoh plot pada tahap penyituasian yaitu, menceritakan tentang alasan Indira berada di Singapura untuk melanjutkan kuliah. 


\section{c. Latar}

Sayuti berpendapat dalam karya sastra latar dibedakan menjadi tiga macam, yaitu: latar tempat, waktu, dan sosial. Latar berfungsi untuk mendukung jalannya cerita. (dalam Wiyatmi, 2009:40). Sesuai pendapat di atas, menganalisis latar pada novel $D B L S$ mencakup, latar tempat, latar waktu, dan latar sosial. Latar tempatnya diceritakan di Singapura dan Bali. Latar waktu digambarkan pengarang pagi, siang, sore dan malam, serta latar sosialnya mengenai kehidupan tokoh Indira. Selanjutnya, dapat dijelaskan hubungan antarunsur intrinsik tersebut.

\section{Analisis Sosiologi Sastra}

\section{a. Aspek Sosial}

Aspek sosial adalah segala sesuatu yang berkaitan dengan manusia dan lingkungannya, serta hubungan antarmanusia yang terjadi dalam kehidupan bermasyarakat. Berikut ini dipaparkan salah satu contoh analisis aspek sosial pada novel $D B L S$ karya Helga Rif.

Upacara ngaben atau pelebon Niang tinggal satu minggu lagi. Berbagai keperluan untuk upacara ini sedang dipersiapkan oleh semua pihak (Rif, 2015:107).

Berdasarkan kutipan di atas, diketahui masyarakat Bali di dalam novel DBLS melakukan interaksi sosial antar perorangan dengan bentuk kerja sama. Masyarakat Indonesia menyebut bentuk kerja sama dengan nama gotong royong. Seperti dalam novel $D B L S$, Indira dan keluarga akan mengadakan upacara ngaben Niang, masyarakat sekitar pun membantu mempersiapkan dan menjaga keamanan agar upacara tersebut dapat berjalan lancar.

\section{b. Aspek Moral}

Moral adalah norma etika di dalam kehidupan masyarakat (Wiyatmi, 2009:109). Berikut ini dipaparkan salah satu contoh analisis aspek moral pada novel $D B L S$ karya Helga Rif.

Tokoh Indira yang bertanggung jawab pada pekerjaan, dengan menyelesaikan tugasnya. Meskipun Indira sudah mengundurkan diri dari perusahaan tempatnya bekerja. Hal tersebut dapat dilihat pada kutipan di bawah ini.
Aku melihat Aji yang sedang duduk di ruang keluarga, ditemani Ibu sedang menonton televisi. Aku baru saja mengirimkan gambargambar kupu-kupu terbaruku dengan sayap patah kepada asisten Mr. Howard melalui $e$ mail. Walau aku telah keluar dari perusahaan tersebut, setidaknya aku harus menyelesaikan pekerjaan dan tugasku terhadap Mr. Howard. Begitu selesai mengirimkan gambar-gambar tersebut melalui e-mail, aku merasa lega. Semoga Mr. Howard menyetujui gambargambarku tersebut (Rif, 2015:227).

\section{c. Aspek Pendidikan}

Pendidikan adalah proses mendidik untuk mengubah perilaku seseorang agar menjadi lebih baik dan dapat menambah ilmu pengetahuan. Jenis pendidikan dibagi menjadi dua, yaitu pendidikan formal dan informal. Berikut ini dipaparkan salah satu contoh analisis aspek pendidikan pada novel $D B L S$ karya Helga Rif.

Singapura. Ternyata sudah lima tahun aku berada di sini. Aku masih ingat ketika memohon kepada $A j i$ dan Ibu untuk mengambil kuliah di bidang desain busana setelah aku menamatkan kuliah di Fakultas Ekonomi di Bali. Aku mencintai fashion dan senang membayangkan jika aku membuat baju sendiri dengan karyaku suatu hari nanti (Rif, 2015:1-2).

Berdasarkan kutipan di atas, diketahui Indira melaksanakan pendidikan formal pada tingkatan perguruan tinggi. Setelah menyandang predikat sarjana ekonomi di Bali, Indira melanjutkan pendidikannya di Singapura dengan mengambil jurusan desain busana.

\section{d. Aspek Ekonomi}

Alfred Marshall mengemukakan ekonomi adalah studi tentang umat manusia dalam usaha mengkaji bagian dari tindakan individu dan sosial yang paling dekat dengan pencapaian dan penggunaan kesejahteraan material (dalam Alam, 2013:1). Untuk mengetahui status sosial tokoh berdasarkan ekonomi, maka akan digunakan stratifikasi sosial. Berikut ini dipaparkan salah satu contoh analisis aspek ekonomi pada novel $D B L S$ karya Helga Rif.

Maximilian adalah pemimpin di perusahaan tekstil tempat Indira bekerja. Maximilian juga merupakan anak dari 
pemilik perusahaan tekstil tersebut. Ayah Maximilian sudah tidak memimpin perusahaan lagi karena sakit jantung. Maka dari itu, Ayah Maximilian menugaskan Maximilian dan kakaknya yang bernama Michael untuk mengelola perusahaan tersebut. Dilihat dari latar belakang sosialnya Maximilian termasuk masyarakat kelas atas. Hal tersebut dapat dilihat pada kutipan di bawah ini.

"Kebetulan saya adalah atasan Indira. Perusahaan tekstil tersebut adalah milik orang tua saya yang kini diserahkan kepada anak-anaknya untuk dikelola karena orang tua saya lebih memilih cuti," jawab Max. Rupanya Max menyembunyikan fakta bahwa sesungguhnya ayahnya sedang sakit jantung sehingga tidak lagi mampu memimpin perusahaan miliknya sendirian lagi. Semua kewenangan telah dilimpahkan kepada anakanaknya, maximilian dan Michael, sejak dua tahun lalu, sesaat setelah aku mulai bekerja di sana (Rif, 2015:130).

\section{e. Aspek Percintaan}

Cinta adalah suatu perasaan yang mendorong seseorang untuk memiliki, menyayangi, dan melindungi orang-orang yang dicintainya. Berikut ini dipaparkan salah satu contoh analisis aspek percintaan pada novel $D B L S$ karya Helga Rif.

Di perusahaan tempatnya bekerja, Indira mendapatkan kekasih. Laki-laki tampan pengganti Bisma tersebut bernama Maximilian. Sifat dan perlakuan Maximilian sangat berbeda jauh dengan perlakuan Bisma terhadap Indira. Maximilian terlihat sangat mencintai Indira dan mampu membuat Indira bahagia saat bersamanya. Dapat dilihat pada kutipan di bawah ini.

Aku masih tak percaya, Max, seorang laki-laki mapan, jatuh cinta kepadaku. Mungkin aku tampak seperti asisten Max ketika berada di sisinya. Pandangan sinis kerap diberikan beberapa rekan kerjaku, yang terang-terangan menunjukkan menyukai Max. Membuatku gusar dan terkadang kehilangan kepercayaan diri. Namun, Max selalu mampu menghiburku dan tak malumalu menunjukkan bahwa kami memang memiliki hubungan istimewa di depan orang- orang yang tampak tak menyukaiku (Rif, 2015:8).

\section{SIMPULAN}

Novel DBLS karya Helga Rif adalah sebuah karya sastra yang menceritakan kehidupan seorang wanita Bali. Dalam penelitian novel $D B L S$, yang digunakan sebagai bahan analisis adalah unsur intrinsik dan aspek sosiologis. Terdapat tiga unsur intrinsik yang dianalisis yaitu: penokohan, plot, dan latar.

Tokoh pada novel $D B L S$ dibedakan menjadi tiga, yaitu: tokoh utama adalah Indira; tokoh sekunder adalah Maximilian, Gung Wah, dan orang tua Indira; serta tokoh komplementer adalah: Iswari, teman Indira, Tante Rani, dan Gus Brahma. Kemudian, penokohannya dapat dianalisis melalui dimensi fisiologis, sosiologis, dan psikologis.

Plot pada novel DBLS dianalisis menggunakan lima tahapan, yaitu: tahap penyituasian, pemunculan konflik, peningkatan konflik, klimaks, dan penyelesaian. Latar pada novel DBLS mencakup, latar tempat, latar waktu, dan latar sosial. Dalam novel $D B L S$, latar tempatnya diceritakan di Singapura dan Bali. Latar waktu digambarkan pengarang pagi, siang, sore dan malam, serta latar sosialnya mengenai kehidupan tokoh Indira.Penelitian ini juga menjelaskan hubungan antarunsur intrinsik tersebut.

Aspek sosiologis yang dianalisis pada novel $D B L S$ yaitu: aspek sosial, aspek moral, aspek pendidikan, aspek ekonomi, dan aspek percintaan. Aspek sosial ditunjukkan pada kehidupan masyarakat Bali yang saling membantu (gotong royong) bila ada acara, ramah terhadap orang asing, berkomunikasi menggunakan bahasa Bali dan Inggris serta melaksanakan adat yang berlaku.

Aspek moral yang ditemukan pada novel $D B L S$ yaitu moral baik. Moral baik digambarkan pada Indira yang bertanggung jawab pada pekerjaan, meminta izin kepada orang tua, tidak memaksakan kehendak, menerima keputusan seseorang, perduli terhadap teman dan menghormati orang tua.

Aspek pendidikan yang dianalisis meliputi jenis pendidikan formal dan informal. Tokoh Indira, Gung Wah, Iswari, 
dan Gus Brahma pada novel DBLS mendapatkan pendidikan formal hingga perguruan tinggi. Selain itu, pengarang juga menggambarkan Indira dan Iswari mendapatkan pendidikan informal yang diberikan oleh Ibu.

Aspek Ekonomi tokoh-tokoh dianalisis dengan menggunakan stratifikasi sosial. Stratifikasi sosial tersebut dapat diketahui melalui pekerjaan dan kekayaan yang dimiliki tokoh-tokoh dalam novel $D B L S$. Masyarakat kelas atas digambarkan tokoh Maximilian, sedangkan masyarakat kelas menengah digambarkan melalui tokoh Indira, $A j i$, dan Gung Wah. Dalam novel $D B L S$ tidak ada tokoh yang digambarkan golongan masyarakat kelas bawah.

Aspek Percintaan yang terdapat pada novel $D B L S$ menceritakan kisah cinta beda agama antara Indira dengan Maximilian. Tokoh-tokoh yang terlibat dalam aspek percintaan adalah Indira, Bisma, Maximilian, orang tua Indira dan Gung Wah. Bisma merupakan mantan kekasih Indira yang berperilaku buruk terhadap Indira. Maximilian kekasih Indira yang sangat mencintai Indira, begitupun Indira juga mencintai Maximilian. Namun, orang tua Indira tidak merestui hubungan Indira dengan Maximilian dan menjodohkan Indira dengan saudaranya yang bernama Gung Wah, yang juga mencintai Indira. Kisah cinta $A j i$ yang dapat menerima kekurangan Ibu juga diceritakan dalam novel $D B L S$.

\section{REFERENSI}

Alam, S. 2013. Mandiri Ekonomi Jilid 1 Untuk SMA/MA Kelas X. Jakarta: Erlangga.

Aniswanti, Anik dan Sri Wahyuningtyas. 2016. Aspek Sosial dalam Novel Partikel karya Dewi Lestari: Tinjauan Sosiologi Sastra. Caraka: Jurnal Ilmiah Kebahasaan, Kesastraan, dan Pemelajarannya, Vol. 3, No. 1.

Budianta, Melani. 1989. Teori Kesusastraan (diterjemahkan dari Theory of Literature oleh Wellek dan Warren). Jakarta: PT. Gramedia.
Endraswara, Suwardi. 2013. Metode Penelitian Sastra. Yogyakarta: CAPS (Center for Academic Publishing Service).

Gunawan, I Wayan Agus. 2015. Aspek-Aspek Sosial dalam Novel Kukul Bulus karya Nyoman Manda. Humanis: Journal of Arts and Humanities, Vol. 10, No. 2.

Gunawan, Rahmat, dkk. 2019. Aspek-Aspek Sosial Novel Rantau 1 Muara karya Ahmad Fuadi. Widyaparwa: Jurnal Ilmiah Kebahasaan dan Kesastraan, Vol. 47, No. 1.

Hidayat, Ryan. 2017. Aspek Sosiologi Sastra dalam Novel Menggapai Matahari karya Dermawan Wibisono. Retorika: Jurnal Bahasa, Sastra, dan Pengajarannya, Vol. 10, No. 2.

Ihsan, Nur Laili. 2018. Upacara Kematian dalam Tradisi suku Toraja dalam Novel Puya ke Puya karya Faisal Oddang: Kajian Sosiologi Sastra. Humanis: Journal of Arts and Humanities, Vol. 22, No. 1.

Lestari, Anna Dwi. 2018. Representasi Kebudayaan Bali dalam Novel Di Bawah langit yang Sama karya Helga Rif (Kajian Interpretatif Simbolik Clifford Geertz).Bapala, Vol. 5, No. 2.

Marlina dan H. Hilaluddin Hanafi. 2017. Realitas Sosial Kehidupan Tokoh Utama dalam Novel Toba Dreams karya TB Silalahi. Jurnal Bastra: Bahasa dan Sastra, Vol. 1, No. 4.

Nurgiyantoro, Burhan. 2012. Teori Pengkajian Fiksi. Yogyakarta: Gadjah Mada University Press.

Prasetiyo, Dedy. 2017. Analisis Aspek Sosiologi Sastra dalam Novel Kidung Cinta Buat Pak Guru karya Mira. Jurnal Sekolah, Vol. 2, No. 1. 
Prasetyo, Pamungkas Tri. 2013. Kajian Sosiologi Sastra dalam Novel Kubur Ngemut Wewadi karya A.Y. Suharyono dan Kemungkinan Pembelajarannya di Kelas XI SMA. Aditya: Jurnal Pendidikan, Bahasa, Sastra, dan Budaya Jawa, Vol. 2, No. 4.

Raharjo, Yusuf Muflikh, dkk. 2017. Kajian Sosiologi Sastra dan Pendidikan Karakter dalam Novel Nun Pada Sebuah Cermin karya Afifah Afra serta Relevansinya dengan Materi Ajar di SMA. Jurnal Pendidikan Indonesia, Vol. 6, No. 1.

Rif, Helga. 2015. Di Bawah Langit yang Sama. Jakarta Selatan: Gagasmedia.

Rondiyah, Arifa Ainun, dkk. 2017. Aspek Sosial Budaya Masyarakat Makassar pada Novel Natisha karya Khrisna Pabichara. Kandai, Vol. 13, No. 2.

Siswanto, Wahyudi. 2013. Pengantar Teori Sastra. Yogyakarta: Aditya Media Publishing.

Syarifuddin. 2018. Kajian Struktural dan Sosiologi Sastra dalam Novel Seputih Hati yang Tercabikkarya Ratu Wardarita. Jurnal Kata: Penelitian tentang Ilmu Bahasa dan Sastra, Vol. 2, No. 2.

Sukada. 1987. Pembinaan Kritik Sastra Indonesia. Bandung: Angkasa

Tarigan, Henry Guntur. 2015. Prinsip-Prinsip Dasar Sastra. Bandung: CV. Angkasa.

Wiyatmi. 2009. Pengantar Kajian Sastra. Yogyakarta: Pustaka Book Publisher. 